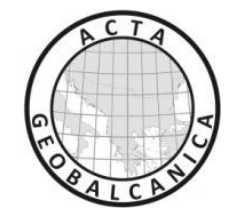

\title{
THE BAUXITE DEPOSITS OF SEYDIŞEHIR REGION (MORTAŞ AND DOĞANKUZU DEPOSITS); THEIR GEOLOGICAL, MINERALOGICAL AND GEOCHEMICAL CHARACTERISTICS
}

\author{
Celalettin Uyanik $^{1}$, Kerim Kocak ${ }^{2}$, Adnan Doyen ${ }^{2}$ \\ ${ }^{1}$ N.Erbakan University, Konya, Turkey; ${ }^{2}$ Selcuk University Konya, Turkey; \\ Corresponding author: cuyanik@konya.edu.tr
}

\begin{abstract}
Turkey hosts essential bauxite deposits, typically of the karstic-type. The most economically important bauxite deposits of Turkey form in the Seydişehir-Akseki region of the central Taurides Mountains. The Mortaş and Doğankuzu deposits are the most important deposits in that region. The bauxite beds contain boehmite, hematite, rutile, smectite, quartz, diaspore, calcite, pyrite, marcasite and goethite. Brown to red-colored bauxite minerals are massive, oolitic - pisolitic textured. The Seydisehir schists could be possible parent rocks of bauxites, and have unearthed acidic source (mostly granite) with hornblende and plagioclase minerals. The schists were compositionally mature with minimal alkali feldspar sediments.

The Mortaş deposit is $400 \mathrm{~m}$ long and up to $40 \mathrm{~m}$ thick; it averages $10 \mathrm{~m}$ thick. It has about 5 million tons of ore reserves, with $\sim 50$ percent $\mathrm{Al}_{2} \mathrm{O}_{3}$. The Doğankuzu bauxite deposit is situated $2 \mathrm{~km}$ southwest of the Mortaş deposit, with 14.9 million metric tons of ore at 61 percent $\mathrm{Al}_{2} \mathrm{O}_{3}$. The Doğankuzu ore was deposited on a fault-controlled karst surface of Cenomanian limestone succession, which was overlain by 5- to 10-cm-thick Santonian limestones. The bauxite has been mined by the Seydisehir aluminum factory, which was founded in 1973, and privatized in 2005. The plant is capable to produce 65.000 ton liquid aluminum per year, around 15\% of Turkey's Aluminum demand.
\end{abstract}

Keywords: Geology, bauxite, karstic, Tauride, Seydisehir.

\section{INTRODUCTION}

The study area is located in the Tauride Belt of southern Turkey (Fig.1), at where six bauxite provinces are located. These are (1) the Milas-Yatağan (Muğla) Province, (2) the Bolkardağı (Karaman) Province, (3) the Tufanbeyli-Saimbeyli-Kadirli Province, (4) the Seydişehir-Akseki Province (5) the Payas-Islahiye Province, and (6) the IspartaŞarkikaraağaç Province. The Seydisehir - Akseki bauxite province contains too many (>100 occurrences) Mediterranean type, paleo-karst bauxite deposits, nevertheless only a few are large enough to be of value (Fig.1,2). 


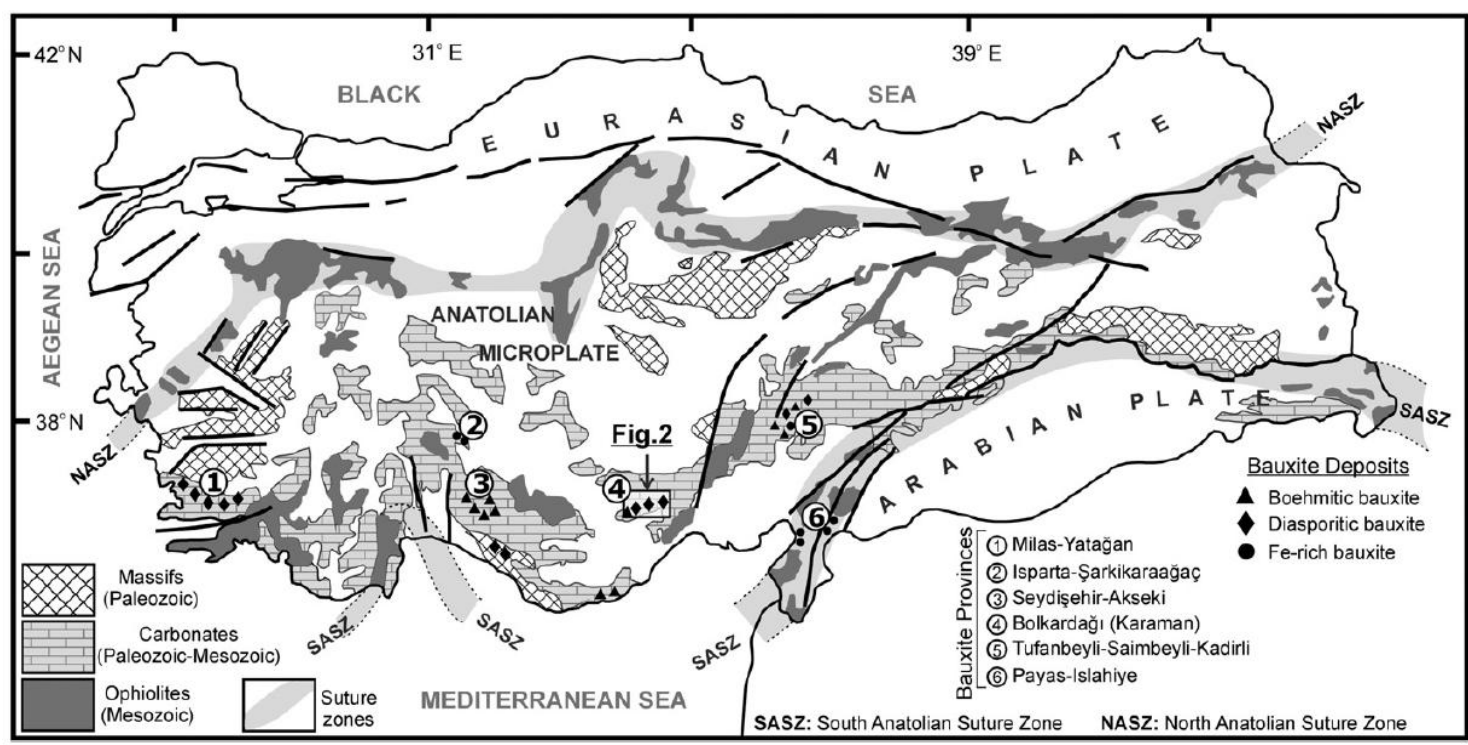

Figure 1: Bauxite deposits of Tauride belt, Turkey [1]

\section{GEOLOGIC SETTING}

In the central Taurides Mountains, there are major autochthonous and allochthonous tectonostratigraphic units. The autochthonous unit includes lower Paleozoic phyllite and graywacke known as the Seydisehir schist, which was unconformably overlied by Triassic and Jurassic limestone and dolomitic limestone.

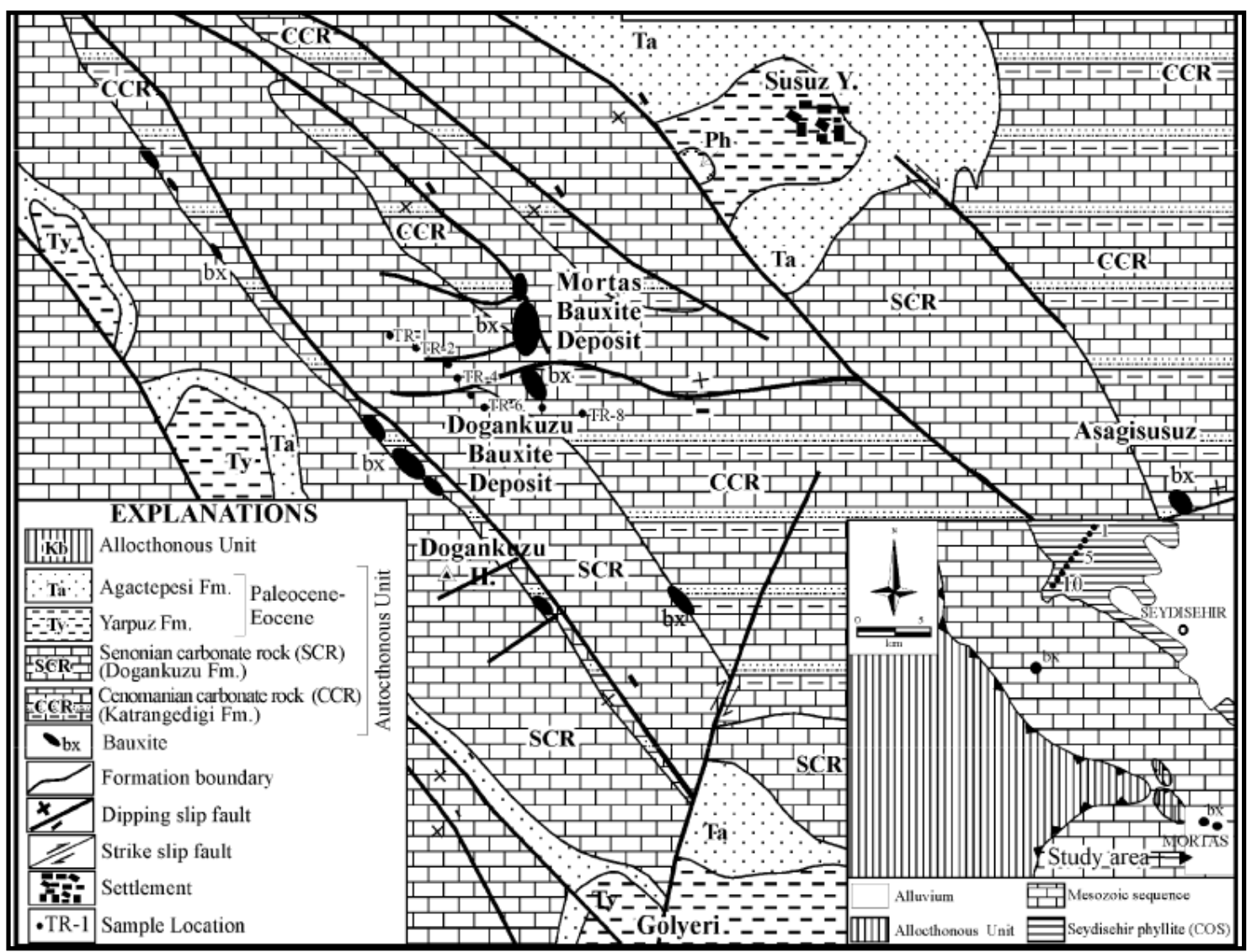

Figure 2: Geological map of the Seydisehir-Akseki bauxite province [2] 
Cretaceous rocks are made up of limestone, dolomitic limestone, which have thickness more than $1000 \mathrm{~m}$, and associated bauxites (Fig.2). Paleocene and Eocene limestone and sandstone (Fig.3) conformably rest on the Cretaceous rocks. From the north onto the autochthonous basement, all the units were obducted during the Oligocene by Hadim nappes, which consists of two tectonostratigraphic subunits: serpentinized ultramafic-mafic rocks and limestone and dolostone of Permian age. Posttectonic sedimentary rocks contain alluvial fan deposits of Miocene and Pliocene ages.
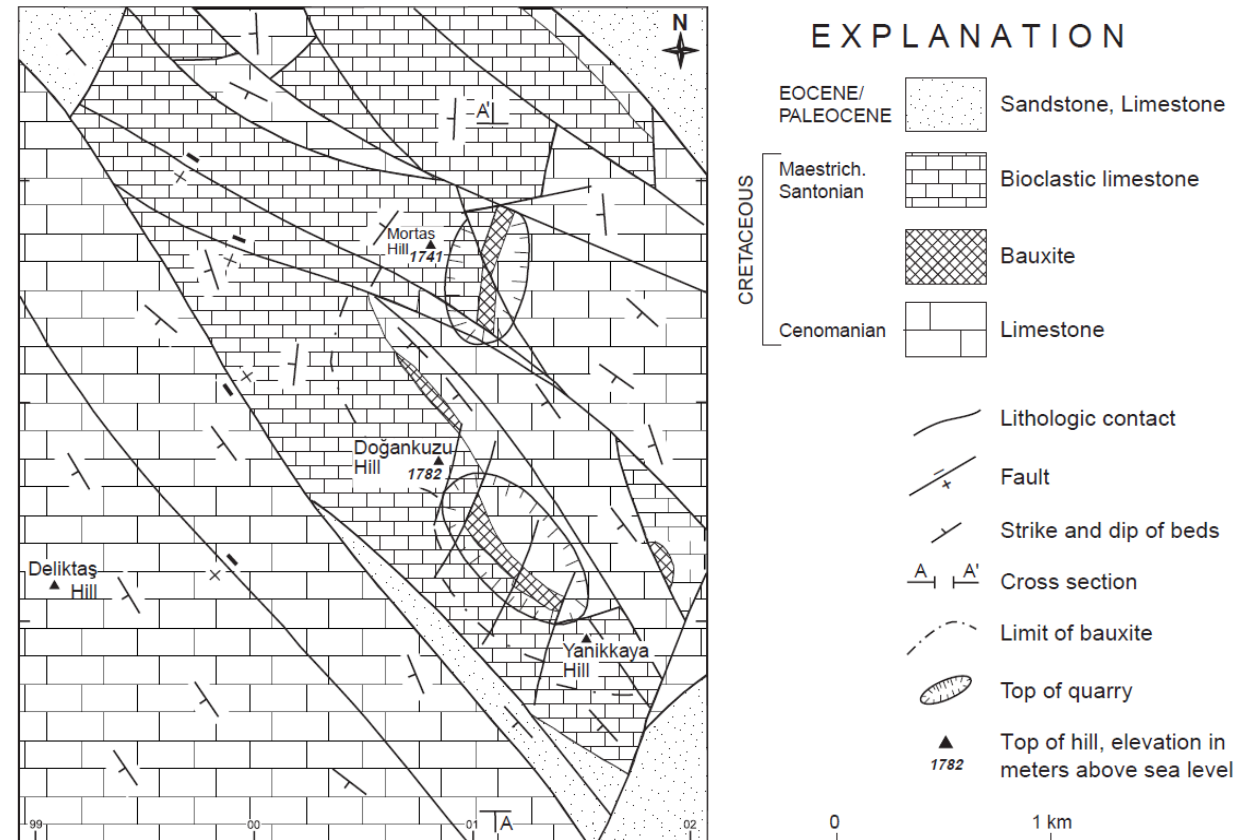

Figure 3: Geological map of Geologic map of the Mortas and Doğankuzu bauxite district [3]

\section{BAUXITE DEPOSITS}

In the Seydisehir - Akseki area, there are economically important bauxite deposits [2,3,4], the most important of which are Mortas, and Doğankuzu deposits mined by the Seydisehir aluminum company. The deposits are of karst unconformity-type deposits placed unconformably between Cenomanian and Santonian shallow marine limestones. Bauxite minerals are brown to red, massive, oolitic - pisolitic textured. Mineralizations formed at the crest of the Taurides Mountains more than 1,500 m above sea level, and have roughly northsouth trend, with thickness varying from 1 to $40 \mathrm{~m}$. They are often cut by various normal faults. The Mortas deposition is one of the most important bauxite mines currently operating in Turkey. The exploration studies taken place from 1970 to 1980, show that the Mortas bauxite deposit have 10.9 million metric tons of ore, with $\sim 50$ percent $\mathrm{Al}_{2} \mathrm{O}_{3}$ (Table 1). The lensoidal deposit is $950 \mathrm{~m}$ in length, $350 \mathrm{~m}$ in width and an average thickness of $40 \mathrm{~m}$. By 1999, six million metric tons of ore has been mined, leaving about 5 million tons of ore reserves. The Doğankuzu bauxite deposit, located $2 \mathrm{~km}$ southwest of the Mortas deposit, has 14.9 million metric tons of ore, with $\sim 61$ percent $\mathrm{Al}_{2} \mathrm{O}_{3}$ (Table 1). Ore was deposited on fault-controlled karst surface of Cenomanian limestone succession, and overlain by 5 - to 10 -cm-thick Santonian limestone [3]. The ore from both deposits is transported to the Seydisehir aluminum factory, which was established in 1973, put into operation at full capacity in 1977. 
Table 1: Average of the bulk rock analyses of the bauxites (DK: Doğankuzu, MT: Mortas) and Seydisehir schists.

\begin{tabular}{|c|c|c|c|c|}
\hline & |DK[3] & TVIT2] & $\begin{array}{l}\text { caltepe } \\
\text { S.sehir }\end{array}$ & $\begin{array}{l}\text { southern } \\
\text { S.sehir }\end{array}$ \\
\hline & bauxite & bauxite & schist & schist \\
\hline Number & 10 & 54 & 10 & 2 \\
\hline SiO2 & 5.25 & 7.40 & 65.00 & 70.20 \\
\hline Al2O3 & 61.09 & 49.80 & 14.50 & 13.54 \\
\hline $\mathrm{Fe} 2 \mathrm{O3}$ & 17.44 & 16.70 & 6.20 & 5.44 \\
\hline MgO & 0.21 & 0.10 & 1.60 & 1.11 \\
\hline $\mathrm{CaO}$ & 0.15 & 5.70 & 1.90 & 0.42 \\
\hline $\mathrm{Na} 2 \mathrm{O}$ & 0.18 & 0.01 & 1.10 & 1.51 \\
\hline K2O & 0.23 & 0.30 & 2.60 & 2.29 \\
\hline TiO2 & 2.93 & 2.10 & 1.00 & 0.84 \\
\hline P2O5 & & 0.02 & 0.20 & 0.13 \\
\hline MnO & & 0.01 & 0.04 & 0.02 \\
\hline Cr2O3 & & 0.04 & 0.01 & 0.03 \\
\hline LOI & 12.24 & 17.20 & 5.70 & 3.95 \\
\hline SUM & 99.73 & 99.70 & 100.00 & 100.09 \\
\hline La & & 137.60 & 58.10 & 42.1 \\
\hline $\mathrm{Ce}$ & & 221.00 & 124.60 & 84.95 \\
\hline $\operatorname{Pr}$ & & 31.70 & 13.70 & 10.26 \\
\hline Nd & & 124.70 & 54.00 & 37.40 \\
\hline Sm & & 24.20 & 10.10 & 7.60 \\
\hline Eu & & 4.90 & 2.00 & 1.55 \\
\hline Gd & & 20.60 & 8.50 & 8.06 \\
\hline Tb & & 3.50 & 1.40 & 1.11 \\
\hline Dy & & 19.10 & 7.80 & 6.31 \\
\hline Ho & & 3.80 & 1.50 & 1.23 \\
\hline $\mathrm{Er}$ & & 11.20 & 4.50 & 3.57 \\
\hline Tm & & 1.80 & 0.70 & 0.54 \\
\hline Yb & & 12.40 & 4.30 & 3.76 \\
\hline Lu & & 1.90 & 0.70 & 0.56 \\
\hline
\end{tabular}

The plant privatized in 2005, processes 550.000 tone / year bauxite ore; in its red mud pool, sodium aluminate $\left(\mathrm{NaAlO}_{2}\right)$ solution is obtained by precipitation of the non-soluble compounds (iron, silica etc.). Alternatively, İt is capable to produce 65.000 ton liquid aluminum per year around $15 \%$ of Turkey's Aluminum demand.

\section{MINERALOGY AND GEOCHEMISTRY}

The minerals in bauxites are boehmite, hematite, rutile, smectite, quartz, calcite and tridymite. Where mineralized by sulfides, the ore also comprises pyrite, marcasite, and in places diaspore, with minor kaolinite, anatase, and in some samples goethite [2,3].

Table-1 shows that Dogankuzu bauxites are enriched in $\mathrm{Al}_{2} \mathrm{O}_{3}, \mathrm{Fe}_{2} \mathrm{O}_{3}, \mathrm{MgO}, \mathrm{Na}_{2} \mathrm{O}$ and $\mathrm{TiO}_{2}$ contents, and depleted in $\mathrm{SiO}_{2}, \mathrm{CaO}$ and $\mathrm{K}_{2} \mathrm{O}$ in comparing with Mortas ones. The Upper Cambrian-Lower Ordovician Seydisehir schist, made up of metamorphosed shale and greywacke, suggested to be a possible parent rock for the bauxites [2, 4]. Accordingly, REE pattern of the Mortas bauxites and Seydisehir schists, namely Caltepe and Southern Seydisehir, show consistent pattern to each other (Fig. 4). They are characterized by LREE enrichment [in 
Mortas bauxites and Seydisehir schist, $(\mathrm{La} / \mathrm{Sm})_{\mathrm{N}}: 3.6,3.5$, respectively] and almost flat HREE [in Mortas bauxites and Seydisehir schist, $(\mathrm{Eu} / \mathrm{Yb})_{\mathrm{N}}: 1.12,1.17$, respectively]. They also show slightly concave upward REE pattern, with pronounced negative Eu (Mortas bauxites and Seydisehir schists: Eu/Eu*: 0.70, 0.62, respectively) anomaly, indicating a source with plagioclase and hornblende. Fig. 5 also shows an unearthed acidic source for the shales. Fig.6 confirms acidic parents, but probably mostly granite in composition, for the schists. It has been suggested that materials derived from acidic source deposited in Paleotethys Ocean as shales of the Seydisehir Formation during the Late Cambrian - Early Ordovician time [2]. In the Seydisehir schists, Index of Compositional Variability [ICV $=\left(\mathrm{Fe}_{2} \mathrm{O}_{3} \mathrm{tot}+\mathrm{K}_{2} \mathrm{O}+\mathrm{Na} \mathrm{O}_{2} \mathrm{O}+\mathrm{CaO}+\right.$ $\left.\mathrm{MgO}+\mathrm{MnO}+\mathrm{TiO}_{2}\right) / \mathrm{Al}_{2} \mathrm{O}_{3}$ ] is 0.93 (average), suggesting that most shales were compositionally mature and were likely dominated by recycling. Ratios of $\mathrm{K}_{2} \mathrm{O} / \mathrm{Al}_{2} \mathrm{O}_{3}$ in the schists are less than 0.4 suggests minimal alkali feldspar in the original shale [7].

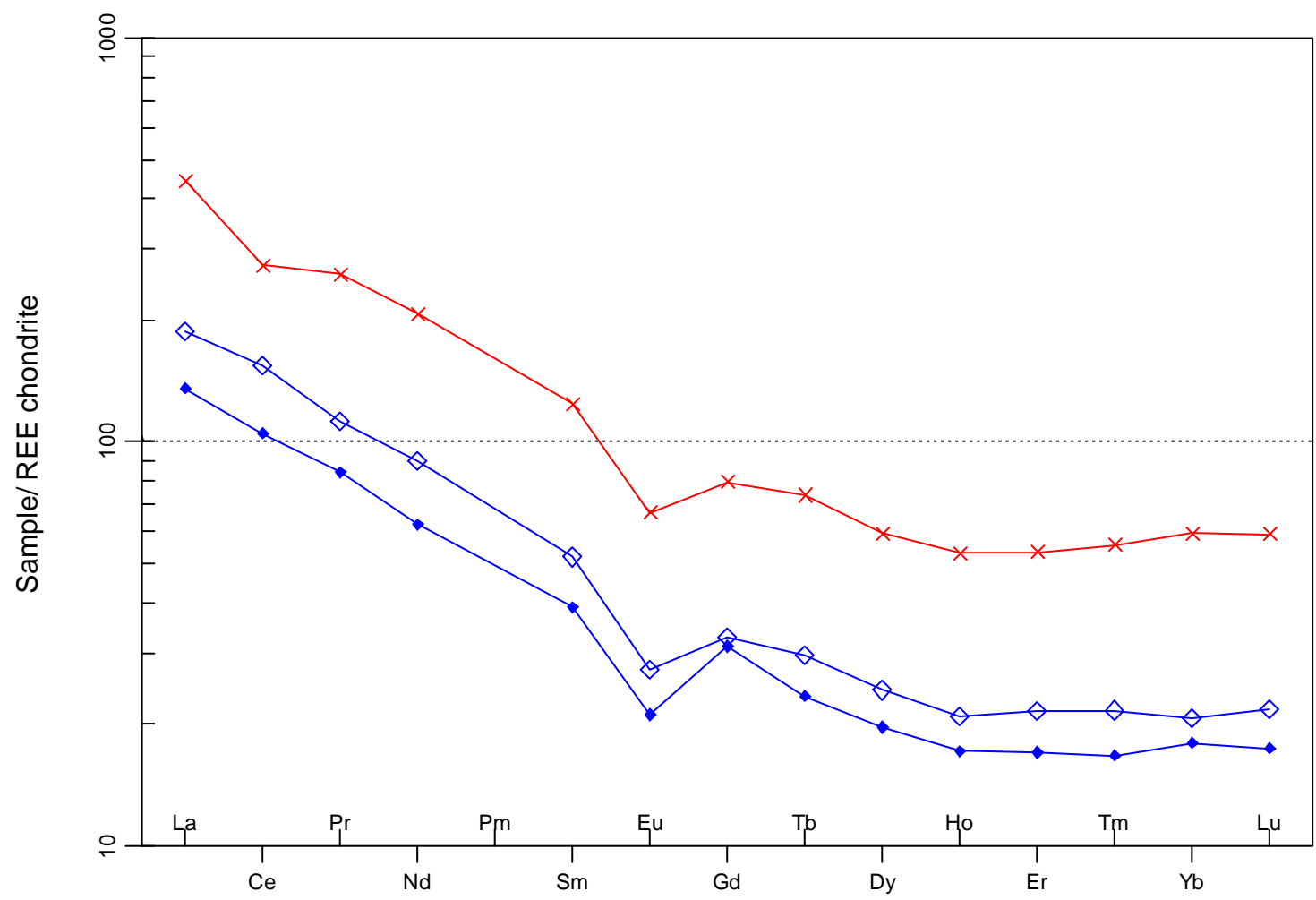

Figure 4: Chondrite normalized [5] REE pattern of the Mortas bauxite (x),and Seydisehir schists (Caltepe: $\searrow$, Southern Seydisehir:

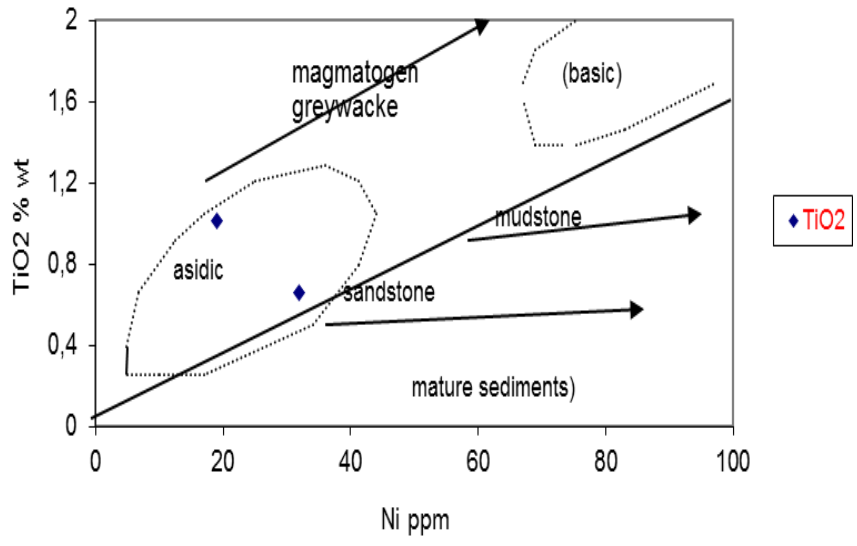

Figure 5: $\mathrm{TiO}_{2} \%$ wt versus Ni ppm diagram, indicating an acidic source for the Southern Seydisehir schists [6]. 


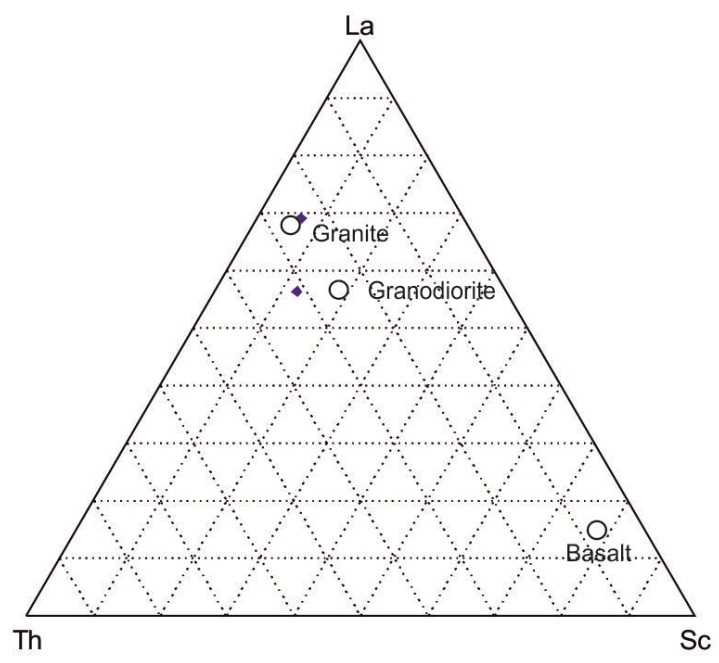

Figure 6. A La-Th-Sc plot of the Seydisehir schists [7].

\section{CONCLUSIONS}

Karst unconformity-type Mortas and Dogankuzu bauxite deposits, associated with Mesozoic limestones, are the major source of $\mathrm{Al}$ in Turkey. Major oxides in the mineralizations $\operatorname{are~} \mathrm{Al}_{2} \mathrm{O}_{3}$, $\mathrm{Fe}_{2} \mathrm{O}_{3}, \mathrm{SiO}_{2}, \mathrm{TiO}_{2}$ and $\mathrm{CaO}$. The bauxites were suggested to have parent rock of Upper Cambrian - Lower Ordovician Seydisehir schist, which have an unearthed acidic source (mostly granite) with hornblende and plagioclase minerals.

\section{REFERENCES}

[1] Hanilçi, N., Geological and geochemical evolution of the Bolkardaği bauxite deposits, Karaman, Journal of Geochemical Exploration, 133, 2013, pp118-137,

[2] Karadag, M.M., Kupeli, S., Arik, F., Ayhan, A., Rare earth element (REE) geochemistry and genetic implications of the Mortas- bauxite deposit (Seydisehir / Konya -Southern Turkey), Chemie der Erde 69, 2009, pp 143-159.

[3] Öztürk, H., Hein, J. R., Hanilçi, N., Genesis of the Dogankuzu and Mortas, Bauxite Deposits, Taurides, Turkey: Separation of $\mathrm{Al}, \mathrm{Fe}$, and $\mathrm{Mn}$ and Implications for Passive Margin Metallogeny, Economic Geology, 97, , 2002, pp1063-1077.

[4] Özlü, N., Etude géologique minéralogue et géochmıque des bauxites de la région D'Akseki-Seydisehir Taurus occidental - Turquie: Unpublished Ph.D. dissertation, Pierre Marie Curie University, Paris, 1978, pp 455.

[5] Boynton, W.V., Cosmochemistry of the Rare Earth Elements: Meteorite studies. In Rare earth elements, Edited by P. Henderson. Elsevier, Amsterdam, The Netherlands, 1984, pp. 63-114.

[6] Floyd, P.A., Winchester, J.A., Park, R.G., Geochemistry and tectonic setting of Lewisian clastic metasediments from the Early Proterozoic Loch Maree Group of Gairloch, N.W. Scotland: Precambrian Research, 45(1-3), 1989, pp 203-214.

[7] Cox, R., Low, D.R., Cullers, R.L. The influence of sediment recycling and basement composition on evolution of mudrock chemistry in the southwestern United States. Geochim. Cosmochim. Acta 59, 1995, pp 2919-2940. 